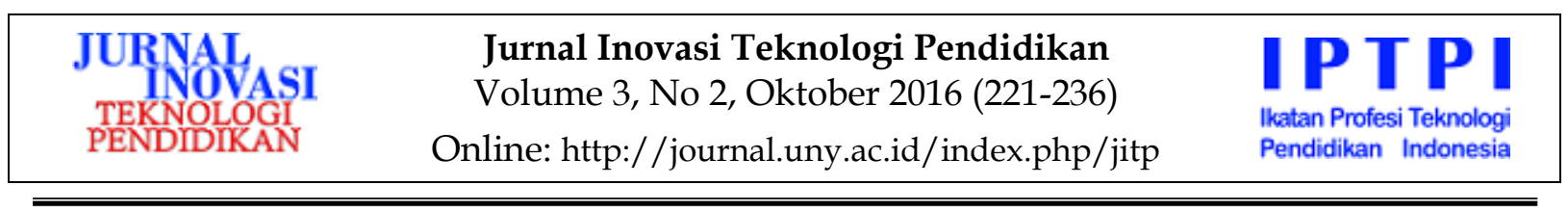

\title{
PENGEMBANGAN MULTIMEDIA INTERAKTIF PEMBELAJARAN KIMIA PADA MATERI HIDROKARBON UNTUK SISWA KELAS XI SMA
}

\author{
Nazalin, Ali Muhtadi \\ SMAN 1 Tomia Waktobi Sulawesi Tenggara, FIP Universitas Negeri Yogyakarta \\ chemy.alhin85@gmail.com, ali_bintangku@yahoo.co.id
}

\begin{abstract}
Abstrak
Penelitian ini bertujuan untuk menghasilkan produk multimedia interaktif pembelajaran kimia pada materi hidrokarbon untuk siswa SMA kelas XI, dan mengungkapkan kelayakan produk multimedia interaktif yang dikembangkan. Penelitian ini menggunakan metode penelitian pengembangan (R\&D), yang terdiri atas tiga tahapan, yaitu perencanaan, desain, dan pengembangan. Tahap perencanaan meliputi identifikasi ruang lingkup materi, karakter siswa, pengumpulan sumber, diskusi ide awal, dan penetapan rencana tampilan. Tahap desain meliputi analisis instruksional serta pembuatan flowchart dan storyboard. Tahap pengembangan meliputi penyiapan teks, grafik, audio, dan video, penggabungan bagian, pembuatan materi pendukung, uji alfa, revisi, uji beta, serta validasi program. Hasil penelitian menunjukkan: (1) produk yang dihasilkan adalah multimedia interaktif pembelajaran kimia pada materi hidrokarbon yang terdiri dari kompetensi, materi ajar, evaluasi, dan game; dan (2) produk yang dikembangkan layak digunakan sebagai media pembelajaran kimia materi hidrokarbon berdasarkan validasi ahli media dengan hasil penilaian baik, validasi ahli materi dengan hasil penilaian sangat baik, penilaian oleh siswa dengan hasil penilaian sangat baik, serta produk yang dikembangkan efektif untuk meningkatkan prestasi belajar kimia siswa pada materi hidrokarbon.
\end{abstract}

Kata Kunci: pengembangan multimedia, multimedia interaktif, pembelajaran kimia, hidrokarbon

\section{DEVELOPING CHEMISTRY TEACHING INTERACTIVE MULTIMEDIA ON HYDROCARBON COURSE FOR CLASS XI STUDENTS OF SENIOR HIGH SCHOOL}

\author{
Nazalin, Ali Muhtadi \\ SMAN 1 Tomia Waktobi Sulawesi Tenggara, FIP Universitas Negeri Yogyakarta \\ chemy.alhin85@gmail.com, ali_bintangku@yahoo.co.id
}

\begin{abstract}
This research aims to develop chemistry teaching interactive multimedia on hydrocarbon course for class XI students of senior high school, and reveal the appropriateness of the developed chemistry teaching interactive multimedia. This study uses research and development $(R \mathcal{E} D)$, which consists of three phases, including planning, design, and development. The planning stage includes the identification of the scope of the material, the student's character, the collection of sources, discussion of the initial idea, and the determination of a display. Instructional design phase includes the analysis and the making flowchart and storyboards. The development phase includes the preparation of text, graphics, audio, and video, the incorporation of parts, manufacturing support materials, alpha testing, revision, beta testing, and validation programs. The results are as follows. (1) The developed product is chemistry teaching interactive multimedia on hydrocarbon course consisting of competence, teaching material, evaluation, and game. (2) The developed product is appropriate to use as chemistry teaching media on hydrocarbon course, based on the media experts' validation shows a good result, the subject matter experts validation shows a very good result, the students' evaluation shows a very good result, and the developed product is effective to increase students' chemistry learning achievement on hydrocarbon course.
\end{abstract}

Keywords: multimedia development, interactive multimedia, teaching chemistry, hydrocarbon 


\section{Pendahuluan}

Kimia merupakan salah satu mata pelajaran yang diajarkan pada Sekolah Menengah Atas (SMA). Carroll \& Sherman (2008, p.15) menyatakan bahwa bagi sebagian besar orang, kimia telah diidentifikasi dengan bau, ledakan, racun, perang, dan kanker. Menurut Kean \& Middlecamp (1985, pp.5-8), karakteristik materi dari ilmu kimia, yaitu: materi kimia yang bersifat abstrak, ilmu kimia merupakan penyederhanaan dari yang sebenarnya, materi kimia yang berurutan dan berkembang dengan cepat, ilmu kimia tidak hanya sekedar memecahkan soal-soal tetapi juga siswa harus mempelajari deskripsi seperti fakta-fakta kimia, aturan-aturan kimia, serta materi yang dipelajari dalam ilmu kimia sangat banyak. Dari dua hal tersebut menyebabkan ilmu kimia sering dianggap sebagai mata pelajaran yang sulit dipahami sehingga siswa enggan untuk mempelajari kimia. Hal ini tercermin dari data skor ujian nasional mata pelajaran kimia pada Tabel 1.

Tabel 1. Hasil Ujian Nasional Mata Pelajaran Kimia di SMAN 1 Tomia dan SMAN 2 Tomia

\begin{tabular}{llccc}
\hline \multirow{2}{*}{ No Nama Sekolah } & \multicolumn{3}{c}{ Rata-rata Skor UN Kimia } \\
\cline { 3 - 5 } & Tahun & Tahun & Tahun \\
& 2012 & 2013 & 2014 \\
\hline 1. SMAN 1 Tomia & 4,56 & 5,14 & 3,89 \\
2. SMAN 2 Tomia & 4,60 & 5,40 & 3,61 \\
\hline
\end{tabular}

Salah satu materi dalam pelajaran kimia di SMA adalah hidrokarbon. Hidrokarbon memiliki karakteristik materi yang umumnya tidak disukai dan dirasa sulit oleh para siswa. Karakteristik materi hidrokarbon adalah sebagai berikut: (1) materi hidrokarbon mempunyai tingkat keabstrakan yang tinggi karena menyangkut wujud, sifat, dan karakter atom karbon yang tak kasat mata (tidak dapat diamati secara langsung) serta menuntut daya khayal untuk memahaminya; (2) materi hidrokarbon berisi fakta-fakta istilah yang jumlahnya banyak dan bervariasi yang harus dihafalkan siswa; (3) istilah-istilah dalam materi hidrokarbon umumnya berupa nama-nama senyawa, sangat asing bagi siswa karena tidak ditemukan dalam kehidupan sehari-hari; dan (4) materi hidrokarbon merupakan materi yang padat, sehingga membutuhkan waktu yang lebih panjang dalam penyampaian materi di dalam kelas. Hidrokarbon merupakan dasar materi kimia yang erat kaitannya dengan kehidupan sehari-hari, yang berguna untuk mempelajari konsep-konsep kimia lebih lanjut. Tanpa pemahaman yang baik maka siswa akan kesulitan untuk memahami materi selanjutnya pada tingkatan yang lebih tinggi. Pembelajaran kimia pada materi hidrokarbon belum mencapai hasil yang optimal sehingga siswa kesulitan untuk memecahkan soal-soal yang ada kaitannya dengan materi hidrokarbon (kimia karbon).

Sejumlah permasalahan yang terjadi dalam proses pembelajaran kimia pada pokok bahasan hidrokarbon berdasarkan hasil pengamatan di lapangan sebagai pengajar mata pelajaran kimia dan hasil diskusi dengan beberapa rekan sejawat, di antaranya adalah siswa masih belum bisa menentukan kedudukan atom karbon dalam rantai senyawa karbon, nomor terendah dalam menuliskan tata nama senyawa hidrokarbon, dan isomer dari senyawa hidrokarbon. Akibatnya siswa akan mengalami kesulitan dalam memahami materi yang diajarkan. Hal ini menyebabkan rendahnya tingkat pencapaian standar kompetensi minimal yang harus dikuasai oleh siswa pada materi hidrokarbon.

Untuk membantu siswa dalam memahami materi hidrokarbon, guru sebaiknya menggunakan alat bantu belajar atau media yang dapat memberikan gambaran kongkrit kepada siswa sehingga belajar hidrokarbon bukan hanya sekedar menghafal tetapi lebih dari memahami konsep secara menyeluruh. Media pembelajaran yang digunakan dalam pembelajaran kimia pada meteri hidrokarbon ini sebaiknya mendukung terciptanya pembelajaran kimia yang aktif dan kreatif serta dapat mendorong minat siswa untuk dapat belajar secara mandiri. Belajar akan lebih ber- 
makna dan menyenangkan apabila ada interaksi antara peserta didik dengan guru sebagai motivator dan memfasilitasi kegiatan pembelajaran, serta interaksi siswa dengan media pembelajaran yang digunakan. Berdasarkan hal tersebut diperlukan media yang bisa menjelaskan konsep secara utuh serta dapat digunakan oleh siswa secara aktif dan mandiri.

Salah satu bentuk media pembelajaran yang dapat digunakan adalah multimedia interaktif pembelajaran. Ivers \& Barron (2002, p.2) menyatakan bahwa multimedia merupakan perpaduan berbagai macam media untuk menyajikan informasi. Perpaduan tersebut dapat berupa teks, grafik, animasi, gambar, video dan suara. Dalam Kamus Besar Bahasa Indonesia kata interaktif memiliki makna bersifat saling melakukan aksi; antarhubungan; saling aktif (Kemdikbud, 2015). Domagk, Schwartz, \& Plass (2010, p.2) menyebutkan bahwa interaktivitas dalam konteks pembelajaran berbasis komputer multimedia adalah kegiatan timbal balik antara peserta didik dan sistem pembelajaran multimedia, di mana reaksi dari peserta didik tergantung pada reaksi sistem dan sebaliknya. Mulyasa (2006, p.255) menyatakan bahwa pembelajaran pada hakekatnya adalah proses interaksi antara siswa dengan lingkungannya, sehingga terjadi perubahan perilaku ke arah yang lebih baik. Berdasarkan uraian tersebut dapat disimpulkan bahwa multimedia interaktif pembelajaran kimia adalah pemanfaatan komputer untuk membuat dan menggabungkan teks, grafik, animasi, gambar, video dan suara dengan menggabungkan link dan tool yang memungkinkan siswa melakukan navigasi, berintraksi, berkreasi dan berkomunikasi dengan materi pembelajaran kimia.

Melalui multimedia interaktif pembelajaran ini siswa akan benar-benar merasa belajar langsung melalui eksperimen, demonstrasi, dan kerja laboratorium namun mereka sesungguhnya berada pada ruang kelas. Siswa dapat belajar secara aktif dan mandiri dengan menggunakan multimedia interaktif pembelajaran. Konsep hidrokarbon yang bersifat abstrak da- pat di visualisasikan melalui gambar, animasi dan video yang terdapat dalam multimedia interaktif pembelajaran. Philips (1997, p.12) menyatakan bahwa manfaat penggunaan multimedia pembelajaran berpotensi untuk menciptakan gaya belajar multisensory dan pada saat yang bersamaan mendorong siswa untuk mengeluarkan gaya belajar mereka sebanyak mungkin. Dalam pembelajaran, peran multimedia sangat penting terutama untuk efektivitas pembelajaran. Peran multimedia tampak pada pembelajaran mandiri yang memberi ruang gerak bagi siswa untuk aktif membangun pengetahuan, keterampilan, dan sikap mereka. Munir (2013, pp.113-114) menyatakan bahwa kelebihan menggunakan multimedia interaktif dalam pembelajaran diantaranya adalah: (1) sistem pembelajaran lebih inovatif dan interaktif; (2) pendidik akan selalu dituntut untuk kreatif dan inovatif dalam mencari terobosan pembelajaran; (3) mampu menggabungkan antara teks, gambar, audio, musik, animasi gambar atau video dalam suatu kesatuan yang saling mendukung guna tercapainya tujuan pembelajaran; (4) menambah motivasi peserta didik selama proses belajar mengajar hingga didapatkan tujuan pembelajaran yang diinginkan; (5) mampu menvisualisasikan materi yang selama ini sulit untuk diterangkan hanya sekedar dengan penjelasan atau alat peraga yang konvensional; dan (6) melatih peserta didik lebih mandiri dalam mendapatkan ilmu pengetahuan.

Dalam pembelajaran, peranan multimedia berbasis komputer menjadi semakin penting di masa sekarang, karena sistem multimedia yang terdiri dari komponen media-media (teks, gambar, grafis, animasi, audio dan video) tersebut dirancang untuk saling melengkapi sehingga menjadi suatu sistem yang berdaya guna dan tepat guna, suatu kesatuan menjadi lebih baik daripada jumlah bagian-bagiannya. Penggunaan multimedia berbasis komputer dapat diterima dalam pembelajaran atas dasar mempertinggi proses belajar mandiri serta peran aktif dari siswa. Sistem multimedia berbasis komputer juga 
memberikan rangsangan bagi proses pembelajaran yang berlangsung di luar ruang kelas (Bardi \& Jailani, 2015, p.52)

Memperhatikan uraian tersebut, perlu untuk mengembangkan dan membuat multimedia interaktif peembelajaran kimia pada materi hidrokarbon. Pengembangan multimedia interaktif pembelajaran kimia pada materi hidrokarbon ini dimaksudkan untuk menghasilkan media pembelajaran yang dapat membantu siswa dalam memahami materi hidrokarbon, dan bisa membuat siswa terlibat secara aktif dan mandiri dalam proses pembelajaran, serta dimaksudkan sebagai media yang dapat digunakan dalam proses pembelajaran kimia dikelas sesuai dengan tuntutan Kurikulum 2013 yang harus mengintegrasikan TIK pada proses pembelajaran.

Penerapan teknologi dalam pembelajaran mengakibatkan timbulnya kebutuhan untuk menganalisis proses pembelajaran dan latihan ke dalam komponenkomponen kegiatan atau tugas-tugas yang ada. Teknologi pembelajaran dapat dirumuskan menurut fungsi-fungsi yang berdasar pada tugas-tugas yang timbul sebagai akibat penerapan teknologi dalam proses pembelajaran. Definisi teknologi pembelajaran yang dikeluarkan AECT tahun 1994 sebagai berikut: "Instructional technology is the theory and practice of design, development, utilization, management and evaluation of processes and resources for for learning.". Definisi tersebut dapat diartikan bahwa teknologi pembelajaran adalah teori dan praktek desain, pengembangan, pemanfaatan, manajemen dan evaluasi proses dan sumber daya untuk belajar (Seels \& Richey, 1994, p.10). Berdasarkan definisi teknologi pembelajaran yang dikeluarkan AECT tahun 1994 di atas, pengembangan multimedia interaktif pembelajaran kimia pada materi hidrokarbon yang dilakukan ini masuk pada kawasan (domain) desain, pengembangan (development), dan penilaian. Desain didefinisikan sebagai "proses untuk menentukan kondisi belajar" (Seels \& Richey, 1994, p.32). Kawasan desain meliputi desain sistem pembelajaran, desain pesan, strategi pembelajaran, karakteristik peserta didik. Seels \& Richey (1994, pp.3843) bahwa pengembangan adalah proses menerjemahkan spesifikasi desain ke dalam bentuk fisik. Penilaian adalah kegiatan untuk mengkaji serta memperbaiki suatu produk atau program (Prawiradilaga, 2012, p.54). Perbaikan dilakukan berdasarkan masukan atau informasi yang diterima.

Tujuan penelitian pengembangan ini adalah untuk: (1) menghasilkan produk multimedia interaktif pembelajaran kimia pada materi hidrokarbon untuk siswa SMA kelas XI; dan (2) mengetahui kelayakan produk multimedia interaktif pembelajaran kimia pada materi hidrokarbon untuk siswa SMA kelas XI.

\section{Metode Penelitian}

Penelitian ini menggunakan model penelitian pengembangan atau Research and Development (R\&D) yang diadaptasi dari model pengembangan multimedia interaktif pembelajaran menurut Alessi \& Trollip (2001, pp.409-410). Adapun bagan langkahlangkah penelitiannya disajikan pada Gambar 1.

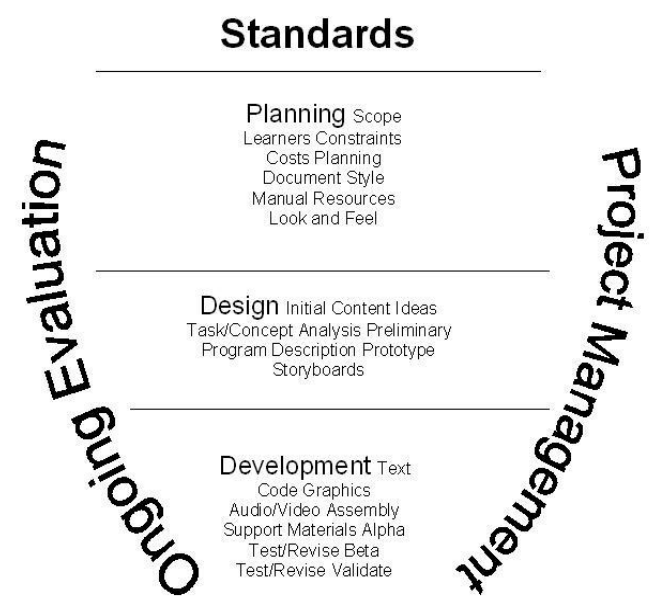

(Alessi \& Trollip 2001, p.410) Gambar 1. Bagan Pengembangan
Multimedia

Penelitian ini dilakukan di SMAN 1 Tomia dan SMAN 2 Tomia, Kabupaten Wakatobi, Sulawesi Tenggara. Adapun waktu penelitiannya adalah mulai dari bulan Mei sampai dengan Desember tahun 2014. Subjek uji coba penelitian adalah 65 
orang siswa kelas XI kelompok peminatan ilmu alam di SMAN 1 Tomia dan SMAN 2 Tomia.

Prosedur pengembangan yang dilakukan meliputi tahap perencanaan (planning), desain (design), pengembangan (development). Pada tahap perencanaan meliputi identifikasi bidang/ruang lingkup materi, identifikasi karateristik siswa, penentuan dan pegumpulan sumber, diskusi ide awal, dan penetapan rencana tampilan. Pada tahap desain meliputi analisis instruksional, dan pembuatan flowchart dan storyboard. Pada tahap pengembangan meliputi penyiapan teks, pembuatan grafik, memproduksi audio dan video, penggabungan bagian, penyiapan materi-materi pendukung, melakukan uji alfa kepada 2 orang ahli media dan 2 orang ahli materi, melakukan revisi, melakukan uji beta terhadap 20 orang siswa, membuat revisi akhir, dan melakukan validasi program kepada 45 orang siswa.

Data diperoleh bersumber dari angket dan tes. Data yang bersumber dari angket diperoleh melalui angket dari ahli materi, ahli media, dan tanggapan siswa, terhadap produk yang dikembangkan kemudian dianalisis. Data yang bersumber dari tes diperoleh dari tes kemampuan siswa pada materi hidrokarbon digunakan untuk mengetahui kelayakan multimedia dari segi pencapaian kompetensi minimal produk pembelajaran yang dihasilkan.

Instrumen yang digunakan untuk mengumpulkan data berupa angket penilaian untuk ahli media yaitu aspek tampilan dan aspek pemrograman, angket untuk ahli materi yaitu aspek pembelajaran dan isi, dan angket untuk siswa yaitu aspek pembelajaran, materi dan aspek tampilan.

Kisi-kisi instrumen yang digunakan untuk penilaian ahli media dapat dilihat pada Tabel 2 .

Kisi-kisi instrumen yang digunakan untuk penilaian ahli materi dapat dilihat pada Tabel 3 .
Tabel 2. Kisi-kisi Instrument untuk Ahli Media

\begin{tabular}{clc}
\hline Aspek & Indikator & No. Butir \\
\hline & Komposisi layout & 1 \\
& Komposisi warna & 2,3 \\
& Ukuran dan bentuk teks & $4,5,6$ \\
Tampilan & Kejelasan musik & 8,9 \\
& Animasi pendukung & $7,10,11,12$ \\
& Desain tombol & 13,14 \\
& Desain kemasan & 15,16 \\
\hline \multirow{4}{*}{ Pemrog- } & Kemudahan penggunaan & $1,2,3,4,5,6,7$ \\
raman & Kemudahan pengaturan & $10,11,12,13$ \\
& Kinerja sistem operasi & 14 \\
& Ukuran file program & 15 \\
\hline
\end{tabular}

Tabel 3. Kisi-Kisi Instrument Untuk Ahli Materi

\begin{tabular}{clc}
\hline Aspek & \multicolumn{1}{c}{ Indikator } & No. Butir \\
\hline \multirow{4}{*}{$\begin{array}{l}\text { Rumusan kompetensi } \\
\text { Pembel- } \\
\text { ajaran }\end{array}$} & $\begin{array}{l}\text { Kejelasan identitas program } \\
\text { penggunaan }\end{array}$ & $6,7,4,5$ \\
& $\begin{array}{l}\text { Ketepatan penerapan strategi } \\
\text { belajar }\end{array}$ & \\
& Kesesuaian materi & 9 \\
& Kejelasan soal dalam program & $13,14,15,16$ \\
\hline \multirow{4}{*}{ Isi } & Uraian materi & $1,2,3,4,5$, \\
& Pemberian contoh & 6,7 \\
& Pemberian animasi & $8,9,10,13$ \\
& Bahasa yang digunakan & 11,12 \\
& Kesesuaian soal & $14,15,16$
\end{tabular}

Kisi-kisi instrument yang digunakan untuk penilaian siswa pada tahap uji beta dan validasi program dapat dilihat pada Tabel 4.

Instrument yang digunakan untuk melihat tingkat penguasaan materi hidrokarbon oleh siswa sebelum (pre-test) dan setelah (post-test) menggunakan multimedia adalah berupa tes. Kisi-kisi yang digunakan disesuaikan dengan indikator yang harus dikuasai siswa dalam pembelajaran kimia pada materi hidrokarbon. Kisi-kisi instrument yang digunakan pada saat pretest dan post-test dapat dilihat pada Tabel 5. 
Tabel 4. Kisi-Kisi Instrument untuk Siswa/Pengguna

\begin{tabular}{clc}
\hline \multirow{2}{*}{ Aspek } & \multicolumn{1}{c}{ Indikator } & $\begin{array}{c}\text { No. } \\
\text { Butir }\end{array}$ \\
\cline { 2 - 3 } Pembelajaran & Kemudahan memilih menu sajian & 1 \\
& Kebebasan memilih menu sajian & 2 \\
& Kejelasan judul program & 3 \\
\cline { 2 - 3 } & Kejelasan rumusan kompetensi & 4 \\
& Kejelasan petunjuk belajar & 5 \\
& Kemudahan keluar dari program & 6 \\
\hline \multirow{5}{*}{ Materi } & Kejelasan isi materi & 1 \\
& Kemudahan materi untuk dipahami & 2 \\
& Kemenarikan materi & 3 \\
& Kejelasan bahasa yang digunakan & 4 \\
Tampilan & Kejelasan petunjuk pengerjaan soal & 5 \\
\hline & Kemudahan teks untuk dibaca & 1 \\
& Kemenarikan kombinasi warna & 2 \\
& Kemenarikan gambar/animasi & 3 \\
& Kemenarikan tombol & 4 \\
& Kemenarikan musik latar & 5 \\
\hline
\end{tabular}

Tabel 5. Kisi-kisi Instrument Soal Pre-Test dan Post-Test

\begin{tabular}{|c|c|c|}
\hline Indikator & $\begin{array}{l}\text { No } \\
\text { Soal }\end{array}$ & $\begin{array}{l}\text { Tingkat } \\
\text { Kognitif }\end{array}$ \\
\hline \multirow{2}{*}{$\begin{array}{l}\text { Mengidentifikasi unsur } \mathrm{C}, \mathrm{H} \text { dan } \mathrm{O} \\
\text { dalam senyawa karbon melalui } \\
\text { percobaan. }\end{array}$} & 1 & C1 \\
\hline & 2 & $\mathrm{C} 1$ \\
\hline \multirow{4}{*}{$\begin{array}{l}\text { Mendeskripsikan kekhasan atom } \\
\text { karbon dalam senyawa karbon. }\end{array}$} & 3 & $\mathrm{C} 2$ \\
\hline & 4 & $\mathrm{C} 2$ \\
\hline & 5 & $\mathrm{C} 1$ \\
\hline & 6 & $\mathrm{C} 2$ \\
\hline \multirow{3}{*}{$\begin{array}{l}\text { Membedakan atom karbon primer, } \\
\text { sekunder, tertier dan kuarterner }\end{array}$} & 7 & C3 \\
\hline & 8 & $\mathrm{C} 3$ \\
\hline & 9 & $\mathrm{C} 3$ \\
\hline \multirow{3}{*}{$\begin{array}{l}\text { Mengelompokkan senyawa } \\
\text { hidrokarbon berdasarkan kejenuhan } \\
\text { ikatan }\end{array}$} & 10 & C3 \\
\hline & 11 & $\mathrm{C} 2$ \\
\hline & 12 & $\mathrm{C} 2$ \\
\hline \multirow{6}{*}{$\begin{array}{l}\text { Memberi nama senyawa alkana, alkena } \\
\text { dan alkuna }\end{array}$} & 13 & $\mathrm{C} 3$ \\
\hline & 14 & $\mathrm{C} 2$ \\
\hline & 15 & $\mathrm{C} 3$ \\
\hline & 16 & $\mathrm{C} 2$ \\
\hline & 17 & $\mathrm{C} 2$ \\
\hline & 18 & $\mathrm{C} 3$ \\
\hline \multirow{2}{*}{$\begin{array}{l}\text { Menyimpulkan hubungan titik didih } \\
\text { senyawa hidrokarbon dengan massa } \\
\text { molekul relatifnya dan strutur } \\
\text { molekulnya. }\end{array}$} & 19 & $\mathrm{C} 3$ \\
\hline & 20 & $\mathrm{C} 3$ \\
\hline \multirow{4}{*}{$\begin{array}{l}\text { Menentukan isomer struktur } \\
\text { (kerangka, posisi, dan fungsi atau } \\
\text { isomer geometri (cis-trans) }\end{array}$} & 21 & C3 \\
\hline & 22 & $\mathrm{C} 3$ \\
\hline & 23 & $\mathrm{C} 3$ \\
\hline & 24 & $\mathrm{C} 3$ \\
\hline $\begin{array}{l}\text { Menuliskan reaksi sederhana pada } \\
\text { senyawa alkana, alkena dan alkuna } \\
\text { (reaksi oksidasi, adisi, substitusi dan } \\
\text { reaksi eliminasi) }\end{array}$ & 25 & $\mathrm{C} 2$ \\
\hline
\end{tabular}

Data yang diperoleh melalui angket dari ahli materi, ahli media, dan tanggapan siswa, terhadap produk yang dikembangkan kemudian dianalisis. Hal ini dimaksudkan untuk menggambarkan karakteristik setiap data, mempermudah memahami data untuk proses analisis selanjutnya dan digunakan sebagai dasar merevisi produk yang dikembangkan. Langkah-langkah dalam analisis data yang digunakan untuk memberikan kriteria kualitas terhadap produk yang dikembangkan adalah data kuantitatif berupa skor penilaian dari ahli media, ahli materi, dan tanggapan siswa yang diperoleh dari angket dianalisis dengan acuan tabel konversi nilai yang diadaptasi dari Widoyoko (2012, pp.111-112).

Tabel 6. Pedoman Pengklasifikasian Skor Penilaian Multimedia

\begin{tabular}{cc}
\hline Rerata skor jawaban & Klasifikasi/kategori \\
\hline $4,21 \leq \mathrm{xi} \leq 5,00$ & SB (Sangat baik) \\
$3,41 \leq \mathrm{xi} \leq 4,20$ & B (Baik) \\
$2,61 \leq \mathrm{xi} \leq 3,40$ & $\mathrm{C}$ (Cukup) \\
$1,81 \leq \mathrm{xi} \leq 2,60$ & $\mathrm{~K}$ (Kurang) \\
$1,00 \leq \mathrm{xi} \leq 1,80$ & $\mathrm{SK}$ (Sangat Kurang) \\
\hline
\end{tabular}

Keterangan :

$\mathrm{xi}=$ rerata ideal tiap item

Untuk menghitung skor rata-rata dalam penilaian terhadap produk yang telah dikembangkan digunakan rumus:

Keterangan:

$$
x i=\frac{\Sigma x}{n}
$$

$\mathrm{xi}=$ skor rata-rata tiap item

$\Sigma x=$ jumlah skor

$n=$ jumlah responden

Dalam penelitian ini ditetapkan nilai kelayakan produk minimal " $\mathrm{B}$ " dengan kategori "baik", sebagai hasil penilaian baik dari ahli materi, ahli media, maupun siswa. Jika hasil penilaian akhir secara keseluruhan pada setiap aspek yang diperoleh nilai minimal untuk setiap aspek yang dinilai berada pada kategori " $\mathrm{B}$ " (baik) maka produk hasil pengembangan tersebut sudah layak digunakan.

Hasil belajar siswa yang diperoleh pada saat post-test dianalisis untuk melihat 
sejauh mana pencapaian tingkat pencapaian kompetensi minimal yang diperoleh siswa. Skor yang diperoleh siswa kemudian dikonversi kedalam skala 4 dengan rumus:

$$
\text { Nilai Konversi }=\frac{\text { skor siswa }}{\text { skor maksimal }} \times 4
$$

Nilai konversi ini kemudian di interpretasikan kedalam bentuk huruf sesuai dengan pedoman pada Tabel 7 .

Tabel 7. Konversi Skor Siswa

\begin{tabular}{cc}
\hline Rentang Angka & Kriteria \\
\hline $3,85-4,00$ & A \\
$3,51-3,84$ & A $^{-}$ \\
$3,18-3,50$ & $\mathrm{~B}^{+}$ \\
$2,85-3,17$ & $\mathrm{~B}^{-}$ \\
$2,51-2,84$ & $\mathrm{~B}^{-}$ \\
$2,18-2,50$ & $\mathrm{C}^{+}$ \\
$1,85-2,17$ & $\mathrm{C}^{-}$ \\
$1,51-1,84$ & $\mathrm{C}^{-}$ \\
$1,18-1,50$ & $\mathrm{D}^{+}$ \\
$1,00-1,17$ & $\mathrm{D}$ \\
\hline
\end{tabular}

Tingkat pencapaian kompetensi minimal yang harus dikuasai siswa adalah sebesar 2,67 atau berada pada rentang nilai B.

Hasil belajar siswa yang diperoleh dari pre-test dan post-test kemudian dianalisis dengan membandingkan skor pretest dan skor post-test. Peningkatan hasil belajar yang terjadi sebelum dan sesudah menggunakan multimedia, diperhitungkan dengan rumus (N-gain) yang ditentukan dengan berdasarkan rata-rata gain skor yang dinormalisasi $(g)$ yaitu perbandingan dari skor gain. Skor gain adalah skor yang diperoleh siswa dari pre-test dan post-test sedangkan skor gain maksimum yaitu skor gain tertinggi yang diperoleh siswa. Ratarata gain yang dinormalisasi ( $N$-gain) (Hake, 1998, p.1) dinyatakan oleh persamaan sebagai berikut:

$$
g=\frac{S \text { post }-S \text { pre }}{\text { S maks }- \text { S pre }}
$$

Keterangan:

$S$ post : Rata-rata Skor Post-test

$S$ pre : Rata-rata Skor Pre-test

$S$ maks : Skor Maksimal
Nilai ini kemudian diinterpretasikan ke dalam tabel klasifikasi nilai gain (Hake, 1998, p.2) pada Tabel 8.

Tabel 8. Interpretasi Nilai Gain

\begin{tabular}{cc}
\hline Nilai $<\mathrm{g}>(\mathrm{n})$ & Kriteria \\
\hline $0,71>1,00$ & Baik \\
$0,31>0,70$ & Sedang \\
$0,00>0,30$ & Jelek \\
\hline
\end{tabular}

\section{Hasil Penelitian dan Pembahasan}

\section{Tahap Perencanaan}

Tahap perencanaan dimulai dengan mengidentifikasi bidang atau ruang lingkup materi hidrokarbon. Tahapan ini dilaksanakan dengan mengidentifikasi Kompetensi Inti dan Kompetensi Dasar pada silabus mata pelajaran kimia kelas XI kelompok peminatan ilmu alam Sekolah Menengah Atas. Silabus digunakan sebagai acuan dalam proses pembelajaran yang dituangkan ke dalam produk multimedia interaktif pembelajaran.

Identifikasi karakteristik siswa kelas XI kelompok peminatan ilmu alam SMA dilaksanakan dengan mengadakan wawancara, observasi, serta angket. Kesimpulan yang diperoleh dari proses identifikasi ini adalah: (1) siswa belum mencapai standar ketuntasan belajar minimal pada materi hidrokarbon yang disebabkan oleh beberapa hal, diantaranya: (a) siswa belum memahami konsep yang diajarkan sehingga kesulitan dalam menentukan kedudukan atom karbon dalam rantai senyawa karbon, nomor terendah dalam menuliskan tata nama senyawa hidrokarbon, dan isomer dari senyawa hidrokarbon, (b) kurangnya perhatian siswa pada saat guru menjelaskan materi, dan (c) penggunaan media yang belum maksimal; (2) siswa termotivasi bila menggunakan media dalam pembelajaran, siswa merasa tertantang untuk menggunakan metode baru dalam proses pembelajaran yang melibatkan siswa dalam proses pembelajaran; (3) siswa tertarik untuk menggunakan multmedia pembelajaran; (4) sebagian besar siswa memiliki 
komputer/laptop; (5) sebagian besar siswa sudah mampu mengoperasikan komputer pada tingkat dasar, (6) siswa berbeda-beda kecepatannya dalam memahami materi yang diajarkan; (7) siswa lebih mudah memahami materi bila guru setelah menjelaskan konsep kemudian diikuti dengan contoh soal; dan (8) tipe belajar yang dimiliki siswa sangat berbeda antara yang satu dengan yang lain.

Pengumpulan sumber terdiri dari 3 bagian, yaitu: (1) pengumpulan materi ajar; (2) identifikasi perangkat lunak yang digunakan dalam proses pembuatan multimedia berupa adobe flash CS6, adobe ilustrator CS6, adobe audition CS6, adobe premiere CS6, corel draw X6, dan ACD Chemsketch, dan berbagai aplikasi pendukung lain; dan (3) pengkajian literatur pendukung. Setelah kegiatan pengumpulan sumber selesai dilaksanakan kegiatan selanjutnya yang dilaksanakan adalah diskusi ide awal.
Diskusi ide awal dilakukan untuk mendiskusikan hal-hal yang berkaitan dengan apa yang dituangkan dalam multimedia pembelajaran. Penetapan rencana tampilan dilakukan untuk mempermudah dalam mendesain multimedia interaktif pembelajaran yang dihasilkan. Dengan adanya penetapan rencana tampilan ini maka elemen-elemen (teks, gambar, video, dan tombol) yang akan dimasukkan dalam multimedia menjadi lebih tertata rapi.

\section{Tahap Desain}

Kegiatan yang dilakukan pada tahap desain beupa: (1) analisis instruksional untuk menganalisis kegiatan yang harus dilakukan oleh siswa agar bisa memahami materi hidrokarbon; dan (2) pembuatan flowchart dan storyboard yang digunakan sebagai panduan dan gambaran multimedia yang akan dihasilkan.

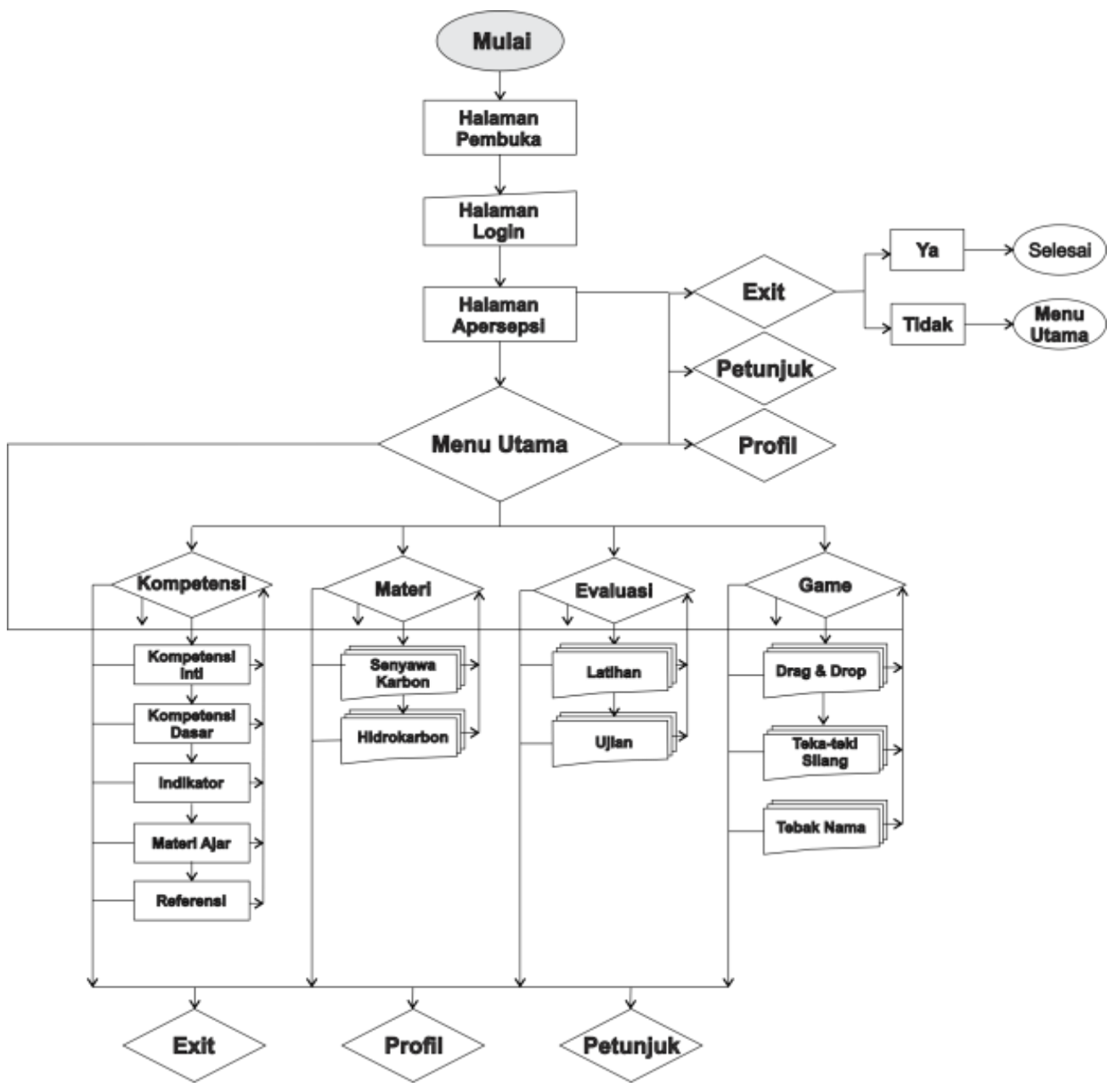

Gambar 2. Flowchart Multimedia Interaktif 


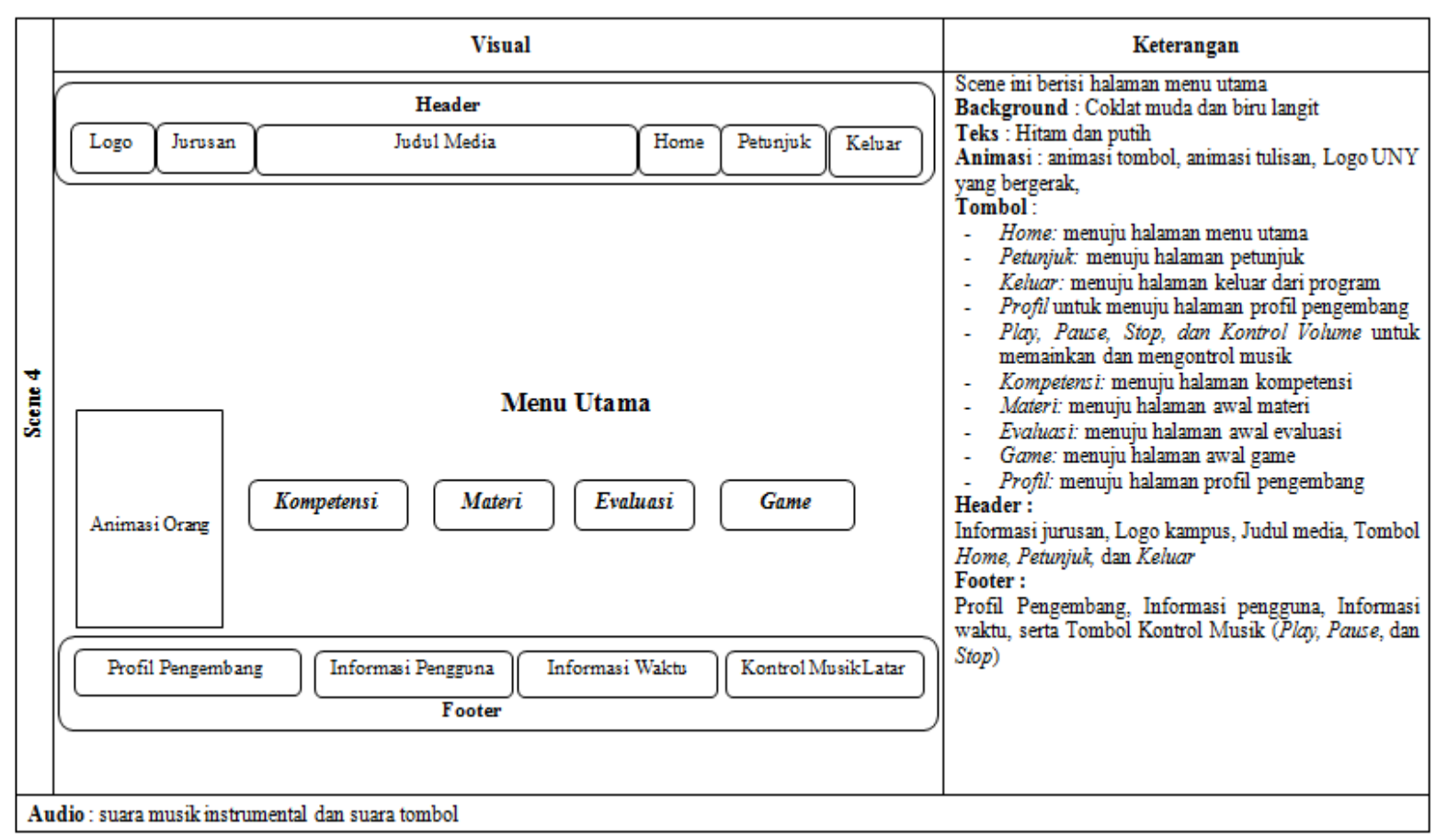

Gambar 3. Storyboard Multimedia Interaktif

Tabel 9. Isi Sofware Multimedia Interaktif Pembelajaran Kimia pada Materi Hidrokarbon

\begin{tabular}{|c|c|c|}
\hline Bagian & Sub-Bagian & Isi \\
\hline \multirow[t]{3}{*}{ Awal } & Intro & Halaman judul multimedia \\
\hline & & Halaman identifikasi pengguna \\
\hline & & Halaman apersepsi \\
\hline \multirow[t]{8}{*}{ Isi } & Petunjuk & Berisi petunjuk untuk menggunakan multimedia \\
\hline & Kompetensi & $\begin{array}{l}\text { Kompetensi inti, kompetensi dasar, indikator, materi ajar yang } \\
\text { harus dikuasai siswa serta referensi. }\end{array}$ \\
\hline & Materi & $\begin{array}{l}\text { Materi disajikan dengan simulasi, animasi, latihan dan contoh } \\
\text { soal }\end{array}$ \\
\hline & 1. Senyawa karbon & $\begin{array}{l}\text { Berisi materi tentang identifikasi atom karbon dalam senyawa, } \\
\text { keunikan atom karbon, rantai atom karbon, atom karbon } \\
\text { primer, sekunder, tersier, dan kuarterner; serta perbedaan } \\
\text { karbon organic dan anorganik. }\end{array}$ \\
\hline & $\begin{array}{l}\text { 2. Hidrokarbon } \\
\text { a. Alkana } \\
\text { b. Alkena } \\
\text { c. Alkuna }\end{array}$ & $\begin{array}{l}\text { Berisi pembahasan tentang rumus umum, aturan penamaan, } \\
\text { isomer, sifat, dan kegunaan dari masing-masing sub pokok } \\
\text { bahasan (Alkana, Alkena, dan Alkuna). }\end{array}$ \\
\hline & Evaluasi & $\begin{array}{l}\text { Berisi soal-soal pemahaman siswa setelah mempelajari materi } \\
\text { pada multimedia pembelajaran. Terdiri dari latihan yang } \\
\text { dilengkapi kunci jawaban, dan ujian. }\end{array}$ \\
\hline & Games & $\begin{array}{l}\text { Berisi } 3 \text { game yaitu tebak nama, drag and drop, dan teka-teki } \\
\text { silang tentang materi yang ada dalam multimedia, sebagai } \\
\text { penyemangat agar siswa tidak merasa bosan. }\end{array}$ \\
\hline & Profil pembuat & Berisi profil singkat pengembang multimedia. \\
\hline Penutup & Ucapan terima kasih & $\begin{array}{l}\text { Ucapan terima kasih telah menggunakan multimedia dan } \\
\text { semoga bermanfaat. }\end{array}$ \\
\hline
\end{tabular}


Tahap Pengembangan

Pada tahap ini kegiatan yang dilakukan antara lain: (1) penyiapan teks yang akan dimasukkan dalam multimedia; (2) pembuatan grafik yang dibutuhkan dalam multimedia; (3) penyiapan file audio dan video yang dituangkan dalam multimedia dengan software pendukung seperti Adobe Audition CS6 dan Corel Draw X6; (4) penggabungan bagian yang telah disiapkan sehingga menjadi produk multimedia dengan menggunakan software Adobe Flash CS6; (5) penyiapan materi pendukung berupa pembuatan desain kemasan luar; (6) melakukan uji alfa kepada 2 orang ahli media dan 2 orang ahli materi untuk mengetahui kelayakan multimedia dari segi pendapat ahli (expert judgement); (7) melakukan revisi berdasarkan masukan dari ahli; (8) melakukan uji beta terhadap 20 orang siswa; (9) membuat revisi akhir berdasarkan masukan dari siswa; dan (10) melakukan validasi program kepada 45 orang siswa.

Bentuk akhir dari produk yang dikembangkan adalah program multimedia interaktif pembelajaran kimia pada materi hidrokarbon untuk siswa kelas XI kelompok peminatan ilmu alam SMA yang dikemas dalam bentuk CD pembelajaran. Multimedia pembelajaran yang dihasilkan meliputi 3 bagian yang disajikan pada Tabel 9 .

Hasil Uji Coba Produk

Analisis Data Uji Alfa

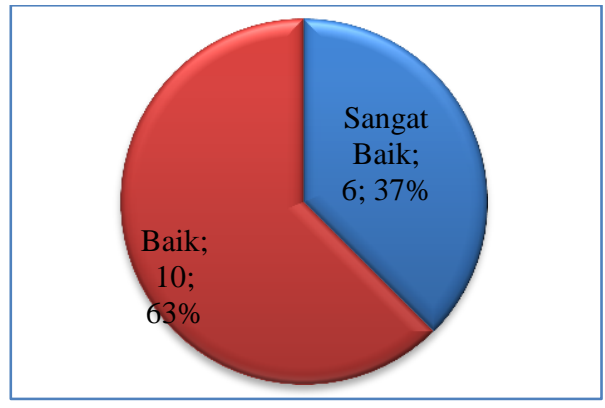

Gambar 4. Persentase Kategori Penilaian Ahli Media pada Aspek Tampilan

Validasi ahli media terdiri dari 2 aspek yaitu aspek tampilan dan pemrog- raman. Hasil perhitungan pada aspek tampilan menghasilkan rerata sebesar 4,22 (sangat baik). Persentase kategori penilaian ahli media pada aspek tampilan dapat dilihat pada Gambar 4.

Penilaian yang dilakukan oleh ahli media pada aspek pemrograman menghasilkan rerata sebesar 4,07 (baik). Persentase kategori penilaian ahli media pada aspek pemrograman disajikan pada Gambar 5.

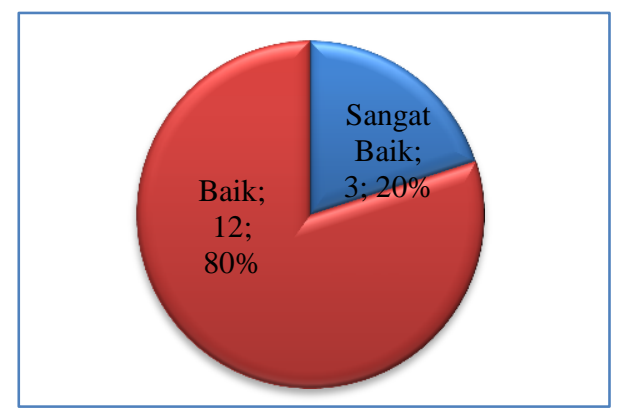

Gambar 5. Persentase Kategori Penilaian Ahli Media pada Aspek Pemrograman

Perbandingan penilaian yang dilakukan oleh dua orang ahli media dapat dilihat pada Tabel 10.

Tabel 10. Rekapitulasi Hasil Penilaian Ahli Media

\begin{tabular}{|c|c|c|c|c|}
\hline \multirow{2}{*}{ Aspek Penilaian } & \multicolumn{3}{|c|}{ Skor Ahli Media } & \multirow{2}{*}{ Kategori } \\
\hline & 1 & 2 & Rerata & \\
\hline Aspek Tampilan & 4,13 & 4,31 & 4,22 & $\begin{array}{c}\text { Sangat } \\
\text { Baik }\end{array}$ \\
\hline $\begin{array}{l}\text { Aspek } \\
\text { Pemrograman }\end{array}$ & 4,00 & 4,13 & 4,07 & Baik \\
\hline Jumlah & 8,13 & 8,44 & 8,44 & \\
\hline Rata-rata & 4,07 & 4,22 & 4,14 & Baik \\
\hline
\end{tabular}

Secara keseluruhan penilaian ahli media pada semua aspek menghasilkan rerata sebesar 4,14 (Baik). Perolehan nilai ini menunjukkan multimedia interaktif pembelajaran yang dikembangkan sudah layak digunakan sebagai media pembelajaran kimia pada materi hidrokarbon untuk siswa SMA kelas XI kelompok peminatan ilmu alam dengan melakukan perbaikan pada bagian-bagian sesuai saran dari para ahli media.

Validasi oleh ahli materi terdiri dari dua aspek yaitu pembelajaran dan isi. Pe- 
nilaian yang dilakukan oleh ahli materi pada aspek pembelajaran menghasilkan rerata sebesar 4,28 (sangat baik). Persentase kategori penilaian ahli materi pada aspek pembelajaran dapat dilihat pada Gambar 6 .

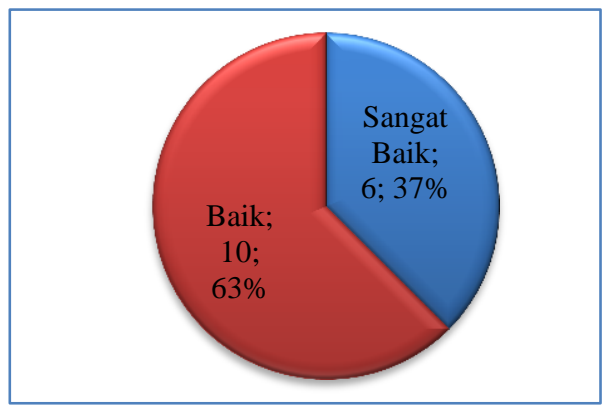

Gambar 6. Persentase Kategori Penilaian Ahli Materi pada Aspek Pembelajaran

Penilaian yang dilakukan oleh ahli materi pada aspek isi materi menghasilkan rerata sebesar 4,28 (sangat baik). Persentase kategori penilaian ahli materi pada aspek isi materi dapat dilihat pada Gambar 7.

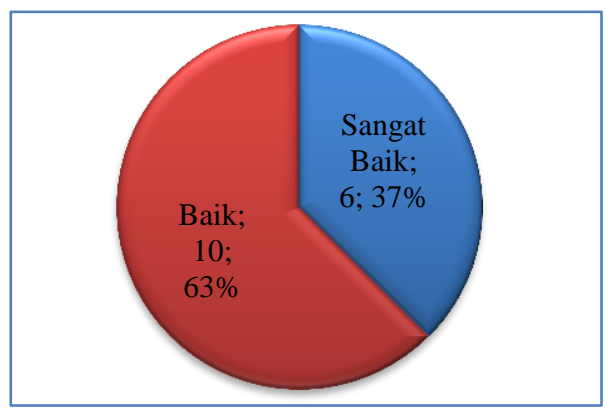

Gambar 7. Persentase Kategori Penilaian Ahli Materi pada Aspek Isi

Perbandingan penilaian yang dilakukan oleh dua orang ahli materi dapat dilihat pada Tabel 11.

Tabel 11. Rekapitulasi Penilaian Ahli Materi

\begin{tabular}{|c|c|c|c|c|}
\hline \multirow{2}{*}{ Aspek Penilaian } & \multicolumn{3}{|c|}{ Skor Ahli Materi } & \multirow{2}{*}{ Kategori } \\
\hline & 1 & 2 & Rerata & \\
\hline $\begin{array}{l}\text { Aspek } \\
\text { Pembelajaran }\end{array}$ & 4,31 & 4,25 & 4,28 & $\begin{array}{l}\text { Sangat } \\
\text { Baik }\end{array}$ \\
\hline Aspek Isi & 4,25 & 4,31 & 4,28 & $\begin{array}{c}\text { Sangat } \\
\text { Baik }\end{array}$ \\
\hline Jumlah & 8,56 & 8,56 & 8,56 & \\
\hline Rata-rata & 4,28 & 4,28 & 4,28 & $\begin{array}{c}\text { Sangat } \\
\text { Baik }\end{array}$ \\
\hline
\end{tabular}

Secara keseluruhan penilaian ahli materi pada semua aspek menghasilkan rerata sebesar 4,28 (Sangat Baik). Perolehan nilai ini menunjukkan multimedia interaktif pembelajaran yang peneliti kembangkan sudah layak digunakan sebagai media pembelajaran kimia pada materi hidrokarbon untuk siswa SMA kelas XI kelompok peminatan ilmu alam dengan melakukan perbaikan pada bagian-bagian sesuai saran dari para ahli materi.

\section{Analisis Data Uji Beta}

Penilaian yang dilakukan oleh siswa pada aspek pembelajaran memiliki rerata sebesar 4,35 (Sangat Baik) dengan semua kategori bernilai "Sangat Baik". Penilaian yang dilakukan oleh siswa pada aspek materi memiliki rerata sebesar 4,44 (Sangat Baik) dengan semua kategori bernilai "Sangat Baik". Sedangkan penilaian yang dilakukan oleh siswa pada aspek tampilan memiliki rerata sebesar 4,31 (Sangat Baik) dengan semua kategori yang bernilai "Sangat Baik". Rangkuman hasil penilaian siswa pada uji beta ini dapat dilihat pada Tabel 12.

Tabel 12. Rekapitulasi Rerata Skor Hasil Penilaian Siswa pada Uji Beta

\begin{tabular}{ccc}
\hline \multicolumn{1}{c}{ Aspek Penilaian } & Skor & Kategori \\
\hline Aspek Pembelajaran & 4,35 & Sangat Baik \\
Aspek Materi & 4,44 & Sangat Baik \\
Aspek Tampilan & 4,31 & Sangat Baik \\
\hline \multicolumn{1}{c}{ Jumlah } & 13,10 & \\
\hline Rata-rata & 4,37 & Sangat Baik \\
\hline
\end{tabular}

Tabel 12 tentang hasil penilaian siswa tersebut menunjukkan bahwa multimedia yang dihasilkan sudah layak untuk digunakan sebagai media pembelajaran kimia untuk materi hidrokarbon pada siswa SMA kelas XI kelompok peminatan ilmu alam.

\section{Analisis Data Validasi Program}

Penilaian yang dilakukan oleh siswa pada aspek pembelajaran memiliki rerata sebesar 4,31 (Sangat Baik) dengan semua kategori bernilai "Sangat Baik". 
Penilaian yang dilakukan oleh siswa pada aspek materi memiliki rerata sebesar 4,44 (Sangat Baik) dengan semua kategori bernilai "Sangat Baik". Sedangkan penilaian yang dilakukan oleh siswa pada aspek tampilan memiliki rerata sebesar 4,31 (Sangat Baik) dengan semua kategori yang bernilai sangat baik. Rangkuman hasil penilaian siswa pada tahap validasi program ini dapat dilihat pada Tabel 13.

Tabel 13. Rekapitulasi Rerata Skor Hasil Penilaian Siswa Tahap Validasi Program

\begin{tabular}{lcc}
\hline \multicolumn{1}{c}{ Aspek Penilaian } & Skor & Kategori \\
\hline Aspek Pembelajaran & 4,31 & Sangat Baik \\
Aspek Materi & 4,26 & Sangat Baik \\
Aspek Tampilan & 4,26 & Sangat Baik \\
\hline \multicolumn{1}{c}{ Jumlah } & 12,84 & \\
\hline Rata-rata & 4,28 & Sangat Baik \\
\hline
\end{tabular}

Tabel hasil penilaian siswa di atas menunjukkan bahwa multimedia yang dihasilkan sudah layak untuk digunakan sebagai media pembelajaran kimia untuk materi hidrokarbon pada siswa SMA kelas XI kelompok peminatan ilmu alam.

Analisis Uji Kelayakan berdasarkan Capaian Hasil Belajar

Analisis ini dimaksudkan untuk mengetahui sejauh mana tingkat pencapaian kompetensi minimal yang harus dikuasai oleh siswa. Tingkat pencapaian kompetensi minimal yang harus dicapai oleh siswa pada materi hidrokarbon pada SMA Negeri 1 Tomia dan SMA Negeri 2 Tomia yaitu sebesar $75 \%$ atau 2,67 pada rentang nilai yang telah ditetapkan dalam Permendikbud nomor 104 tahun 2014 (Kemdikbud, 2014).

Hasil analisis pencapaian kompetensi minimal siswa kelas XI IA1 SMA Negeri 1 Tomia dan siswa kelas XI IA3 SMA Negeri 2 Tomia pada materi hidrokarbon setelah menggunakan multimedia pembelajaran dapat dilihat pada Tabel 14 .

Tabel 14 menunjukkan bahwa tingkat capaian kompetensi minimal telah dilampaui oleh sebagian besar siswa. Dengan demikian dapat dikatakan bahwa multimedia interaktif ini layak dan efektif untuk meningkatkan hasil belajar siswa

Tabel 14. Tingkat Pencapaian Kompetensi Minimal

\begin{tabular}{|c|c|c|c|}
\hline Kelas dan Sekolah & Kriteria & Jumlah & $\begin{array}{c}\text { Persentase } \\
(\%)\end{array}$ \\
\hline \multirow[b]{2}{*}{$\begin{array}{l}\text { XI IA1 } \\
\text { SMAN } 1 \text { Tomia }\end{array}$} & Tuntas & 21 & 95 \\
\hline & $\begin{array}{l}\text { Belum } \\
\text { Tuntas }\end{array}$ & 1 & 5 \\
\hline \multirow{2}{*}{$\begin{array}{l}\text { XI IA3 } \\
\text { SMAN } 2 \text { Tomia }\end{array}$} & Tuntas & 20 & 87 \\
\hline & $\begin{array}{l}\text { Belum } \\
\text { Tuntas }\end{array}$ & 3 & 13 \\
\hline
\end{tabular}

Hasil analisis data hasil belajar menunjukan bahwa terdapat perbedaan antara sebelum dan sesudah belajar menggunakan multimedia. Perbedaan tersebut ditunjukkan pada rerata pre-test dan posttest. Pada pre-test diperoleh rerata 2,38, sedangkan pada post-test diperoleh rerata 3,44 . Selisih antara rerata pre-test dan posttest ini disebut dengan istilah gain score yaitu dengan nilai 0,66 yang mempunyai kriteria sedang.

Persentase kategori dari gain score yang diperoleh secara keseluruhan dapat dilihat pada Tabel 15.

Tabel 15. Kategori Hasil Gain Score Keseluruhan Responden

\begin{tabular}{lcc}
\hline \multicolumn{1}{c}{ Kategori } & Jumlah & Persentase (\%) \\
\hline Jelek & 4 & 9 \\
Sedang & 17 & 38 \\
Baik & 24 & 53 \\
\hline Total & 45 & 100 \\
\hline
\end{tabular}

Data gain score secara keseluruhan disimpulkan bahwa multimedia yang dikembangkan layak dan secara efektif dapat meningkatkan prestasi belajar kimia siswa pada materi hidrokarbon.

\section{Pembahasan}

Multimedia yang dikembangkan dibuat berdasarkan pada beberapa teori belajar dan pembelajaran yaitu behavioristik, kognitif, dan konstruktivistik. Konsep teori behavioristik pada penelitian ini didasarkan pada pendapat Thorndike 
(1923, pp. 1-4) dan Thorndike (1923, p. 96). Bentuk penerapan hukum kesiapan di dalam produk multimedia pembelajaran kimia pada materi hidrokarbon ini diterapkan pada halaman awal apersepsi dari multimedia, di mana pada halaman ini diberikan informasi kepada siswa tentang pentingnya mempelajari materi. Bentuk penerapan hukum latihan pada produk multimedia dalam penelitian ini adalah pada pemberian game, soal-soal latihan dan evaluasi. Game dalam multimedia ini didesain berisi materi, sehingga ketika siswa bermain game maka secara tidak langsung mereka juga belajar tentang materi. Bentuk penerapan hukum pengaruh pada produk adalah pada penyajian respon berupa animasi yang didapat siswa apabila siswa mendapat nilai tertentu setelah evaluasi selesai dikerjakan.

Penerapan teori kognitif pada multimedia pembelajaran yang dikembangkan berdasarkan pada tiga asumsi yang dikemukakan oleh Mayer (2010, pp. 64-68). Tiga asumsi tersebut adalah asumsi DualChannel (saluran ganda), asumsi kapasitas terbatas, dan pemrosesan aktif. Teori kognitif diterapkan pada penyajian halaman tentang urutan cara penentuan nama senyawa hidrokarbon (alkana, alkena, dan alkuna), di mana pada halaman ini proses penentuan nama senyawa hidrokarbon dibuat secara berurutan tahap demi tahap, sehingga siswa dapat mengikuti bagaimana alur penentuan nama senyawa. Selain pada halaman penentuan nama senyawa penerapan teori kognitif dalam multimedia ini juga terlihat pada halaman tentang penentuan isomer senyawa hidrokarbon yang dibuat berurutan tahap demi tahap. Penerapan teori kognitif juga terlihat pada penggunaan kalimat dan gambar atau animasi yang sesuai pada contoh tanpa suara narasi (visual pictorial) agar tidak membebani memori kerja (Working Memory).

Teori konstruktivistik pada penelitian ini di dasarkan pada pendapat yang dikemukakan oleh Heinick, Molenda, Russel, \& Smaldino, (1996, p.7). Penerapan teori konstruktivistik adalah multimedia didesain untuk memberikan kebebasan kepada siswa untuk memahami materi dalam multimedia sesuai dengan alur berpikirnya, siswa diberi kebebasan untuk memilih materi yang mereka pelajari.

Produk multimedia pembelajaran interaktif kimia pada materi hidrokarbon ini merupakan salah satu sumber belajar yang bertujuan agar siswa merasa lebih aktif dalam proses pembelajaran, lebih termotivasi untuk belajar, dan lebih interaktif sesuai dengan kecepatan pemahaman siswa dalam rangka pembelajaran mandiri. Produk yang dikembangkan dapat dijadikan sebagai salah satu sumber belajar bagi siswa kelas XI kelompok peminatan ilmu alam SMA/MA untuk pembelajaran kimia pada materi hidrokarbon, sehingga siswa lebih mudah mengonstruksi pelajaran sesuai dengan kecepatan pemahamannya dan dengan demikian diharapkan pembelajaran kimia pada materi hidrokarbon menjadi lebih mandiri dan bermakna.

Kualitas produk multimedia yang dikembangkan dapat digolongkan sangat baik. Hal ini dibuktikan dari komentar yang diperoleh melalui angket siswa pada uji beta dan validasi produk yang memberikan komentar berupa kesan bahwa produk multimedia pembelajaran yang dikembangkan menarik, menyenangkan dan memudahkan mereka untuk memahami materi hidrokarbon.

Dari hasil capaian kompetensi minimal yang harus dikuasai oleh siswa dan analisis gain score terlihat bahwa multimedia pembelajaran kimia pada materi hidrokarbon ini efektif untuk meningkatkan hasil belajar siswa pada materi hidrokarbon. Hal ini disebabkan multimedia yang dihasilkan dapat digunakan secara berulang-ulang sehingga bermanfaat bagi siswa dalam mempelajari materi tersebut sesuai dengan kecepatan pemahamannya.

Multimedia interaktif pembelajaran kimia materi hidrokarbon ini memiliki kelebihan dan kekurangan. Kelebihan multimedia ini antara lain: (1) dalam penyajian terdapat penggabungan berbagai unsur multimedia (teks, gambar, suara, video, dan interaktivitas) yang membantu siswa 
untuk aktif mengkonstruksi sendiri pengetahuan, pemahaman mereka, dan membuat program multimedia pembelajaran ini menarik juga menambah motivasi belajar siswa, (2) file multimedia ini berbentuk aplikasi (*.exe), sehingga dapat langsung dioperasikan tanpa menginstal software apa pun, (3) terdapat feedback/umpan balik di dalamnya, (4) multimedia pembelajaran ini membantu guru dalam memvisualisasikan materi hidrokarbon yang bersifat abstrak.

Selain kelebihan yang dimiliki, produk multimedia pembelajaran yang dikembangkan memiliki beberapa kelemahan dan keterbatasan. Kelemahan dari produk yang dibuat yaitu tidak dapat disebarkan melalui media internet karena produk ini mempunyai kapasitas file yang besar. Kelemahan lain dari produk yang dikembangkan adalah isi materi pada program multimedia pembelajaran yang dikembangkan tidak dapat diperbaharui sendiri oleh pengguna secara langsung, yaitu guru dan siswa. Produk multimedia pembelajaran yang dikembangkan tidak mempunyai soal kuis yang teracak secara otomatis. Dari segi penerapan kurikulum 2013, evaluasi dalam multimedia ini hanya menekankan pada aspek kognitif saja, dan belum semua kompetensi inti yang harus dikuasai siswa termuat dalam multimedia ini. Oleh karena itu, disarankan dalam menerapkan pembelajaran dengan multimedia ini sebaiknya dipadukan dengan metode yang sesuai untuk mengukur aspek afektif dan psikomotor siswa. Dengan produk multimedia pembelajaran ini diharapkan pembelajaran kimia materi hidrokarbon menjadi lebih menarik, siswa lebih aktif dalam proses pembelajaran, serta menimbulkan motivasi belajar siswa agar dapat meningkatkan keterampilan serta prestasi belajar siswa.

\section{Simpulan dan Saran}

\section{Simpulan}

Produk yang dihasilkan berupa software multimedia interaktif pembelajaran kimia pada materi hidrokarbon yang mencakup halaman apersepsi, kompetensi, materi, evaluasi, dan games. Kompetensi terdiri dari kompetensi inti, kompetensi dasar, indikator keberhasilan, materi ajar, dan referensi. Materi berisi dua topik utama yaitu senyawa karbon dan hidrokarbon (Alkana, Alkena, dan Alkuna). Pada setiap akhir sub pokok bahasan disajikan soal latihan yang dapat membantu siswa dalam memahami materi yang baru saja mereka pelajari. Evaluasi terdiri dari 2 bagian yaitu latihan soal yang dilengkapi dengan kunci jawaban, serta ujian yang harus diselesaikan. Semua soal yang digunakan dalam evaluasi dalam multimedia ini berbentuk pilihan ganda. Games yang disajikan berbentuk permainan tebak nama, drag and drop, serta teka-teki silang.

Produk yang dikembangkan layak digunakan sebagai salah satu alat bantu pembelajaran ditinjau dari hal berikut. Pertama, penilaian ahli media yang menghasilkan rerata sebesar 4,14 (Baik) dengan rincian penilaian pada aspek tampilan memperoleh nilai rata-rata 4,22 (ahli media 1:4,13; ahli media 2:4,31) dengan kategori sangat baik. Sedangkan pada aspek pemrograman memperoleh nilai rata-rata 3,93 (ahli media 1:4,00; ahli media 2:4,13) dengan kategori baik. Kedua, penilaian ahli materi yang menghasilkan rerata sebesar 4,28 (Sangat Baik) dengan rincian penilaian pada aspek pembelajaran memperoleh nilai rata-rata 4,28 (ahli materi $1: 4,31$; ahli materi 2:4,25) dengan kategori sangat baik. Sedangkan pada aspek isi memperoleh nilai rata-rata 4,28 (ahli materi 1:4,25; ahli materi 2:4,31) dengan kategori sangat baik.

Ketiga, hasil uji coba oleh siswa pada tahap uji beta memperoleh nilai ratarata 4,37 dengan kategori sangat baik, dengan rincian pada aspek pembelajaran memiliki rata-rata 4,35 (sangat baik), aspek materi memiliki rata-rata 4,44 (sangat baik), dan aspek tampilan memiliki rata-rata 4,31 (sangat baik). Hasil uji coba oleh siswa pada tahap validasi program memperoleh nilai rata-rata 4,28 dengan kategori sangat baik, dengan rincian pada aspek pembelajaran memiliki rata-rata 4,31 (sangat baik), aspek materi memiliki rata-rata 4,26 (sa- 
ngat baik), dan aspek tampilan memiliki rata-rata 4,26 (sangat baik).

Keempat, Produk multimedia yang dihasilkan efektif digunakan untuk meningkatkan hasil belajar kimia siswa pada materi hidrokarbon yang terlihat dari hasil analisis dengan: (1) capaian kompetensi minimal yang diperoleh siswa pada saat pembelajaran dengan menggunakan multimedia pembelajaran interaktif pada materi hidrokarbon ini adalah sebesar 95\% siswa kelas XI IA1 SMA Negeri 1 Tomia dinyatakan telah mencapai kompetensi minimal serta $87 \%$ siswa kelas XI IA3 SMA Negeri 2 Tomia telah mencapai kompetensi minimal; dan (2) Analisis uji gain score menghasilkan indeks gain score sebesar 0,66 (kategori sedang) dengan rincian pada kategori jelek sebesar $11 \%$, kategori sedang sebesar $36 \%$, dan kategori baik sebesar 53\%.

Saran

Pemanfaatan produk bagi guru sebaiknya mengikuti langkah-langkah berikut: (a) guru menjelaskan terlebih dahulu kepada siswa tentang program dan penggunaannya dengan tujuan siswa lebih mudah memahami materi yang disajikan; (b) penyampaian materi diawali dengan menjelaskan konsep dari materi yang bertujuan mengasah kemampuan siswa, memahami dan mengingat materi yang disampaikan; dan (c) penggunaan multimedia ini, sebaiknya dipadukan dengan model pembelajaran yang bisa digunakan untuk mengukur aspek afektif dan psikomotor siswa, sebagaimana yang ditekankan dalam penerapan kurikulum 2013.

Pemanfaatan produk bagi siswa sebaiknya mengikuti langkah-langkah berikut: (a) siswa membaca dan mempelajari keseluruhan materi secara berurutan dimulai dari kompetensi, materi, evaluasi, dan games. Diskusikan dengan guru atau teman sebaya apabila terdapat kesulitan dalam menjalankan program atau materi yang tidak dipahami; (b) siswa hendaknya terbisaa mengoperasionalkan program dengan tujuan melatih keterampilan siswa dan mengasah daya ingat siswa mengenai materi yang dipelajari; dan (c) siswa hendaknya memperhatikan petunjuk-petunjuk pada program sehingga siswa dapat mengoperasionalkan program dengan mudah.

\section{Daftar Pustaka}

Alessi, S. M., \& Trollip, S. R. (2001). Multimedia for Learning: Methods and Development. Massachusetts: Allyn \& Bacon.

Bardi, B., \& Jailani, J. (2015). Pengembangan Multimedia Berbasis Komputer untuk Pembelajaran Matematika Bagi Siswa SMA. Jurnal Inovasi Teknologi Pendidikan, 2(1), 49-63. Retrieved fromhttp://journal.uny.ac.id/index .php/jitp/article/view/5203/4509

Carroll, W. F., \& Sherman, K. M. (2008). Chemistry in the national education standar (2 ed.). (Penyunting: S. L. Bretz) Washington: American Chemical Society, Education Division.

Domagk, S., Schwartz, R. N., \& Plass, J. L. (2010). Interactivity in multimedia learning: An integrated model. Komputers in Human Behavior Journal, 11-21. Diunduh tanggal 5 September 2014.

Hake, R. (1998). Interactive engagement versus traditional methods: a sixthousand-student survey of mechanics test data for introductory physics course [Versi elektronik]. Am. J. Phys. , 64-74. Diunduh tanggal 2 September 2013.

Heinick, R., Molenda, M., Russel, J. D., \& Smaldino, S. E. (1996). Instructional Media and Technologies for Learning. New Jersey: Prentice Hall.

Ivers, K., \& Barron, A. (2002). Multimedia projects in education: Designing, producing, and assessing (2 ed.). Westport: Libraries Unlimited.

Kean, E., \& Middlecamp, C. (1985). Panduan Belajar Kimia Dasar. 
(Terjemahan: A. H. Pudjaatmaka) Jakarta: Gramedia. (Buku asli diterbitkan tahun 1984).

Kemdikbud. (2014). Permendikbud No. 104 Tahun 2014 tentang Penilaian Hasil Belajar oleh Pendidik pada Pendidikan Dasar dan Menengah. Jakarta.

Kemdikbud. (2015). Kamus Besar Bahasa Indonesia versi online. http://badanbahasa.kemdikbud.go .id/kbbi/index.php. Diakses tanggal 5 Januari 2015.

Mayer, R. E. (2005). The Cambridge Handbook of Multimedia Learning. Cambridge: Cambridge University Press.

Mulyasa, E. (2006). Menjadi guru profesional menciptakan pembelajaran kreatif dan menyenangkan. Bandung: Remaja Rosdakarya.

Munir. (2013). Multimedia: Konsep $\mathcal{E}$ Aplikasi dalam Pendidikan. Bandung: Penerbit Alfabeta.
Seels, B. B., \& Richey, R. C. (1994). Teknologi Pembelajaran: Definisi dan Kawasannya. (Terjemahan: D. S. Prawiradilaga, R. Rahardjo, \& Y. Miarso) Jakarta: IPTPI. (Buku asli diterbitkan tahun 1994).

Philips, R. (1997). The Developers handbooks to Interactive Multimedia: A Practical guide for educational applications. New York: Kogan Page, Ltd.

Prawiradilaga, D. S. (2012). Wawasan Teknologi Pendidikan. Jakarta: Kencana Prenada Media Group.

Thorndike, E. L. (1923). Education. New York: The Macmillan Company.

Thorndike, E. L. (1923). The Psychology of learning (Vols. 2). New York: Columbia University.

Widoyoko, E.P. (2012). Teknik Penyusunan Isntrumen Penelitian. Yogyakarta: Pustaka Pelajar. 